\title{
PEMBATASAN HAK BAGI PEMILIK SERTIFIKAT HAK MILIK ATAS TANAH DI WILAYAH ADAT KEBIRANGGA \\ KECAMATAN MAUKARO KABUPATEN ENDE (STUDI DI WILAYAH ADAT KEBIRANGGA KECAMATAN MAUKARO KABUPATEN ENDE)
}

\author{
Maria Cicilia Pricemarina
}

Dinas Kesehatan Kabupaten Ende

J1. Melati Ende - Flores NTT

Email: maria.pricemarina@gmail.com

\begin{abstract}
The registration of land right was aimed to ensure that the holder of this land right could provide the existence of right holding and also to provide law certainty and law protection to the holder of land right. However, Kebirangga custom was still familiar with right constraint on land right holding especially for the land within the region of Kebirangga custom. Land was only acquired based on the allotment of tanah ulayat by Mosalaki such that fai wazu ana azo (custom citizens) were only considered as the cultivator without the right to transfer land right (selling or enclosing into bank as collateral). It deviated against the characteristic of property right in recent laws and regulations which stated that property right was the right to enjoy article/land in freedom regardless the exercising method whether it was used as collateral or guarantee, or could be transferred to other party, be released voluntarily, or be bestowed as religious donation as long as this should not contravene the existing laws and regulations, and not disturb the right of others. Method of this journal was socio legal research because the research attempted to examine the behavior of individual or community in relative to the law. Result of research indicated that Kebirangga custom region in Maukaro District still could not eliminate the role of custom law in regulating the possession of land right, or even remove the function of Mosalaki as the Chief of Custom. Property right certificate for land with the name of each holder (fai wau ana azo) was seemingly unsuccessful to displace the authority right of Mosalaki for custom property. It might be a fact that there was a dispute over the ownership based on positive law stipulations and also a debate over law certainty between positive law and custom law.
\end{abstract}

Key words: right constraint, property right certificate for land, authority right of mosalaki (chief of custom)

Abstrak
Pendaftaran hak atas tanah bertujuan agar para pemegang hak atas tanah akan dengan mudah
membuktikan bahwa dirinya sebagai pemegang hak serta dapat memberikan jaminan
kepastian hukum dan perlindungan hukum bagi pemegang hak. Namun di wilayah adat
Kebirangga terdapat pembatasan hak bagi pemilik sertifikat hak milik atas tanah di wilayat
adat Kebirangga karena tanah diperoleh berdasarkan pembagian tanah ulayat oleh Mosalaki,
sehingga fai wazu ana azo (warga adat) hanya dipandang sebagai penggarap tanpa mempunyai
hak untuk mengalihkan hak atas tanah tersebut ( menjual atau menjaminkan pada Bank) hal ini 
bertentangan dengan ciri dari hak Milik dalam ketentuan Peraturan perundang-undangan yaitu hak milik adalah hak untuk menikmati suatu benda/ tanah dengan sebebas-bebasnya dijadikan jaminan utang dengan dibebani Hak Tanggungan bisa dialihkan atau beralih kepihak lain, dapat dilepas secara suka rela serta dapat diwakafkan asal tidak bertentangan dengan undangundang atau peraturan lainnya dan tidak mengganggu hak orang lain. Dalam Jurnal ini Peneliti menggunakan metode penelitian socio legal research, yang merupakan penelitian yang menitik beratkan perilaku individu atau masyarakat dalam kaitannya dengan hukum.

Berdasarkan hasil penelitian menunjukkan bahwa di wilayah adat Kebirangga di Kecamatan Maukaro belum mampu menghilangkan peran hukum adat khusus dalam penguasaan hak atas tanah dari Mosalaki sebagai Kepala adat, meskipun telah ada sertifikat hak milik atas nama masing-masing orang (fai wazu ana azo), sehingga hak milik masih menjadi hak Mosalaki yang berlaku hingga saat ini, merupakan fakta masih adanya pertentangan akan kepemilikan berdasarkan ketentuan hukum positif dalam kepastian hukum antara hukum positif dan hukum adat.

Kata kunci: pembatasan hak, sertifikat hak milik atas tanah, hak menguasai oleh mosalaki (kepala adat)

\section{Latar Belakang}

Kepemilikan atas tanah ulayat berkaitan erat dengan hukum adat yaitu keseluruhan aturan yang menjelma dari keputusan keputusan para fungsionaris hukum (dalam arti luas) yang mempunyai kewibawaan (macht,authorithy) serta mempunyai pengaruh dan yang dalam pelaksanaannya berlaku secara serta merta (spontan) dan ditaati dengan sepenuh hati yang diterima dan dipatuhi karena sesuai dengan kesadaran hukum masyarakat."”

Perbuatan hukum yang berkaitan dengan hak untuk menguasai karena tanah adat (tanah ulayat) secara umum mempunyai tiga sifat dasar yaitu:

1. Religio- magis yaitu kepercayaan pada yang gaib atau tersembunyi. Hal ini tertuang dalam penyelenggaraan upacaraupacara keagamaan yang harus mereka lakukan sebelum mereka membuka tanah, atau mengusahakan tanah secara bersama-sama.

2. Kemasyarakatan dalam bentuk adanya rasa tanggung jawab yang harus dipikul oleh masyarakat hukum tersebut atas kejahatan yang terjadi dalam lingkungan wilayahnya. Dan juga adanya larangan bagi persekutuan hukum dan anggotanya untuk menjual tanah ulayat kepada orang asing, serta adanya campur tangan dari masyarakat hukum terhadap tanah-tanah yang digarapnya.

3. Perekonomian dalam bentuk kekuasaan persekutuan hukum dan para anggotanya untuk mengambil manfaat secara bebas (membuka tanah, mendirikan perkampungan, memungut hasil, berburu, menggembala) atas tanah ulayatnya. Sedangkan bagi orang asing yang ingin memanfaatkan tanah ulayat haruslah seijin dari masyarakat hukum

1 I. Gedhe A.B Wiranata, Hukum Adat Indonesia, Cetakan Ke-I, Citra Aditya Bakti, Bandung, 2006, hlm. 14. 
tersebut melalui pemimpinnya dan dengan membayar recognitie. ${ }^{2}$

Dalam Pasal 3 Undang-Undang Nomor 5 Tahun 1960 menyatakan bahwa :

“ Dengan mengingat ketentuan Pasal 1 dan pasal 2 pelaksanaan hak ulayat dan hak-hak serupa itu dari masyarakat-masyarakat hukum adat, sepanjang menurut kenyataannya. Masih ada, harus sedemikian rupa sehingga sesuai dengan kepentingan nasional dannegarayang berdasarkan atas persatuan bangsa serta tidak boleh bertentangan dengan undangundang dan peraturan-peraturan lain yang lebih tinggi “

Dalam wilayah adat Kebirangga pada tahun 2002 oleh Badan Pertanahan Nasional dilaksanakan pendaftaran tanah pertama kali dengan sistem Sistematik (PRONA) hal ini dalam rangka memberikan kepastian hukum mengenai hak-hak atas tanah yang telah dikelola oleh anggota masyarakat adat selama bertahun-tahun bahkan secara turun temurun. Atas persetujuan Mosalaki maka Prona dapat dilaksanakan di wilayah adat Kebirangga sehingga tiap-tiap fai wazu ana azo mempunyai sertifikat atas nama masingmasing, namun Mosalaki masih dominan dalam penguasaan tanah, karena para fai wazu ana azo status hanya sebatas sebagai penggarap atas tanah tersebut, tanah untuk dikelola dan dimanfaatkan saja dengan batasan-batasan sesuai dengan Ketentuan adat yaitu tidak boleh dijual atau dialihkan maupun dijaminkan dengan hak tanggungan di Bank, meskipun telah ada sertifikat hak milik tanah atas nama masing-masing.

Kepemilikan tanah sesuai hak ulayat oleh Mosalaki di wilayah adat Kebirangga di Kecamatan Maukaro tersebut dari perspektif hukum positif diakui dan diatur dalam Bab I Pasal 1 Peraturan Menteri Negara Agraria/Kepala Badan Pertanahan Nasional Nomor 5 Tahun 1999 tentang Penyelesaian sengketa tanah ulayat Ulayat Masyarakat Hukum Adat yang berbunyi : 1). Hak ulayat adalah kewenangan yang menurut hukum adat dipunyai oleh masyarakat hukum adat tertentu atas wilayah tertentu yang merupakan lingkungan hidup para warganya untuk mengambil manfaat termasuk tanah, bagi kelangsungan hidup dan kehidupannya, timbul dari hubungan secara alamiah dan diwariskan dari generasi kegenarasi serta tidak terputus antara masyarakat hukum adat tersebut dengan wilayah yang bersangkutan; 2). Tanah ulayat ialah sebidang tanah yang diatas permukaannya terdapat hak tradisional dan purba dari suatu masyarakat hukum adat tertentu; dan 3). Masyarakat hukum adat adalah kelompok warga masyarakat yang saling terkait satu dengan lainnya oleh suatu aturan adat yang merupakan suatu kesatuan dikarenakan kesamaan teritorial/tempat tinggal ataupun atas dasar keturunan. ${ }^{3}$

Sehingga Sertifikat bagi para milik tanah di

2 Fifik Wiryani, Reformasi Hak Ulayat Pengaturan Hak-hak Masyarakat Adat dalam Pengelolaan Sumber Daya Alam, Setara Press, Malang, 2009, hlm. 21-22.

3 Boedi Harsono, Hukum Agraria Indonesia (Himpunan Peraturan-peraturan Hukum Tanah), Djambatan, Jakarta, 2008, hlm. 63. 
wilayah adat Kebirangga secara penuh sebagai alat bukti yang kuat dan terjamin kepemilikan serta terwujud kepastian hukum sebatas pada kejelasan batas-batas bidang tanah bagi tiap fai wazu ana azo guna menghindari sengketa yang berkaitan dengan batas tanah.

Berdasarkan latar belakang yang diuraikan diatas, maka dapat dirumuskan permasalahannya sebagai berikut:

1. Bagaimana kekuatan hukum dari Sertifikat Hak Milik Atas Tanah di wilayah adat Kebirangga Kecamatan Maukaro Kabupaten Ende berdasarkan pelaksanaan penyertifikatan tanah adat diwilayah adat tersebut?

2. Apakah intervensi dari Kepala Adat (Mosalaki) berkaitan dengan pembatasan hak bagi pemilik sertifikat hak milik atas tanah berdasarkan teori Kepastian Hukum ?

Metode penelitian yaitu metode empirik secara socio legal research yang menitik beratkan perilaku individu atau masyarakat dalam kaitannya dengan hukum serta mempunyai karakteristik yaitu: (1). Menggunakan data sekunder sebagai data awalnya yang dilanjutkan dengan data primer atau data lapangan (bertumpu pada Premis normatif), (2). Definisi operasionalnya dapat diambil dari peraturan perundang-undangan, (3). Akibat dari jenis datanya, maka alat pengumpul data terdiri dari Studi dokumen, Pengamatan (observasi) dan Wawancara,(4).
Pengolahan datanya dilakukan secara kualitatif.

Dalam Penelitian ini wawancara dilakukan pada Bapak Camat Maukaro, Mosalaki Kebirangga dan Mosalaki wilayah adat tetangga, Kepala Desa Kebirangga dan Kepala Desa Kebirangga Tengah, masyarakat adat Kebirangga, , Kepala Seksi pada Kantor Badan Pertanahan Nasional Kabupaten Ende.

\section{Pembahasan}

\section{A. Kekuatan Hukum dari Sertifikat Hak Milik Atas Tanah di Wilayah Adat Kebirangga Kecamatan Maukaro Kabupaten Ende berdasarkan Pelaksanaan Penyertifikatan Tanah Adat}

Keberadaan suatu wilayah adat tidak dapat dipisahkan dari kepemilikan tanah adat yang dimiliki secara komunal dibawa penguasaan dan pengaturan oleh Mosalaki, sebagaimana diatur dalam Konsepsi Hukum Adat bahwa tanah adat yang terdapat dalam lingkungan wilayah suatu masyarakat hukum adat merupakan tanah kepunyaan bersama (komunal) dari semua warga masyarakat hukum adat, dengan amanat dimanfaatkan untuk memenuhi kepentingan bersama dilakukan dibawah pimpinan penguasa adat. ${ }^{4}$

Masyarakat adat tersebut tidak dapat dipisahkan dari tanah hak ulayat di wilayah adat Kebirangga disebut tana Kebi (tanah milik Kebirangga) dan watu Rangga (batu

4 B. Ter Haar sebagaimana dikutip dari Buku Hukum Adat Indonesia, Soerjono Soekanto dalam terjemahan bebasnya, RajaGrafindo Persada, Jakarta, 2012, hlm. 173. 
milik Kebirangga) yang diikat dalam ketentuan hukum adat yang berlaku diwilayah adat tersebut, tanah dipandang sebagai sumber kehidupan manusia.

Pada tahun 2002 berdasarkan persetujuan dari Mosalaki Kebirangga Proyek Operasi Nasional Agraria (PRONA) dilaksanakan di wilayah adat Kebirangga , sehingga tiap-tiap fai wazu ana azo Kebirangga dapat mendaftarkan hak atas tanahnya dan mempunyai sertifikat atas nama mereka masing-masing.

Pelaksanaan PRONA harus dengan persetujuan Mosalaki karena tanah tersebut diperoleh dari pembagian tanah yang dilakukan oleh Mosalaki. Proses pemberian tanah dari Mosalaki secara lisan melalui seremonial adat kepada masyarakat adatnya karena faktor keturunan maupun dari suku lain di luar suku Kebirangga karena faktor territorial yaitu pendatang dari suku Buton, Bugis, Makasar yang telah menetap di wilayah adat Kebirangga dalam waktu yang lama.

Mosalaki memberi ijin untuk mensertifikatkan tanah sebagai pelaksanaan atas kewenangan sekaligus bentuk tanggung jawab Mosalaki dalam memberikan kepastian hukum dalam upaya mencegah konflik perebutan atau penyerobotan lahan antar para fai wazu ana azo yang sering terjadi sebelum tahun 2002, pada sisi yang lebih tinggi bentuk pertanggung jawab terhadap Tuhan (Dua Nggae atau Dewa nggae), dan leluhur (tana watu) dalam memakmurkan para fai wazu ana azo.

Dalam penelitian yang didapati oleh peneliti untuk tanah adat yang belum disertifkat, menurut para nara sumber diantaranya bapak Yoseph Mboro (Mosalaki Kebirangga) yang diwawancara alasannya sebagai berikut:

1. Minimnya pemahaman masyarakat terhadap manfaat, prosedur dan syarat penyertifikat tanahnya dan keterbatasan biaya untuk mengurus sertifikat secara mandiri ;

2. Masyarakat masih menggangap sertifikat sebatas bukti pemilikan tanah guna kepastian batas atas tanahnya dan menghindari penyerobotan lahan/tanah

Tabel: Data Jumlah Sertifikat pada wilayah Adat Kebirangga

\begin{tabular}{|c|l|c|c|c|}
\hline No & \multicolumn{1}{|c|}{ Desa } & $\begin{array}{c}\text { Tersertifikat } \\
\text { (Bidang) }\end{array}$ & $\begin{array}{c}\text { Belum disertifikat } \\
\text { (Bidang) }\end{array}$ & $\begin{array}{c}\text { Jumlah } \\
\text { (Bidang) }\end{array}$ \\
\hline 1 & Kebirangga & 482 & 107 & 589 \\
\hline 2 & Kebirangga Tengah & 130 & 148 & 278 \\
\hline Jumlah & & $\mathbf{6 1 2}$ & $\mathbf{2 5 5}$ & $\mathbf{8 6 7}^{*}$ ) \\
\hline
\end{tabular}

*) Tanah yang belum dibagi baik dalam bidang-bidang tanah maupun tanah yang masih merupakan Tanah Komunal yang dikuasai oleh Kepala Adat (Mosalaki) berupa Hutan atau hamparan tanah.

Sumber: Data Primer dari Kantor Badan Pertanahan Nasional Kabupaten Ende Tahun 2014 dan wawancara dengan Mosalaki Bapak Yoseph Mboro yang diolah 
oleh fai wazu ana azo atau oleh suku lainnya;

3. Masih kuatnya hak menguasai tanah oleh Mosalaki sedangkan para fai wazo ana azo dipandang sebagai penggarap tanah yang harus tunduk pada ketentuan adat yang berlaku di wilayah adat tersebut.

Kekuatan hukum dari sertifikat Hak Milik atas tanah di wilayah adat Kebirangga yaitu hak milik dalam sertifikat diakui, namun tanah tersebut secara adat masih dikuasai oleh Mosalaki sedangkan fai wazu ana azo (pemegang sertifikat Hak Milik) masih dianggap sebagai penggarap dengan kewajiban mentaati ketentuan adat dan terlibat aktif di wilayah adat setiap pelaksanaan seremoni/ upacara adat.

Bapak Melanton Nati,SH sebagai Kepala Seksi Pendaftaran Kantor BPN Kabupaten Ende mengemukakan secara umumnya untuk wilayah Kabupaten Ende intinya manfaat dari penyertifikatan tanahnya yaitu untuk menghindari konflik tanah khususnya tentang batas-batas tanah. Karena sertifikat baru diterbitkan setelah ada kejelasan status tanah, maka hal ini membantu dalam meminimalisir konflik tanah yang terjadi.

Dari hal tersebut diatas dapat dianalisa bahwa kepemilikan tanah dalam suku Kebirangga, hak sepenuhnya tetap berada dalam pengguasaan Mosalaki sedangkan Sertifikat diberikan dalam rangka memastikan batas kepemilikan antar orang- perorang agar tidak terjadi perebutan lahan, sedangkan hak untuk menjual dan atau menggadaikan tanah harus meminta persetujuan Mosalaki sebagai kepala suku dengan maksud agar Mosalaki ikut mengatur dan mengawasi serta menjaga agar tanah yang dimiliki oleh setiap fai wazu ana azo dalam suku Kebirangga tidak berpindah kepemilikan kepada orang lain dengan alasan tanah adalah warisan leluhur dan merupakan pesan dari leluhur agar tanah tidak dijual dengan alasan apapun, karena dari lahir, hidup dan mati ke tanah, serta diwariskan pada anak cucu. Serta jika menjual tanah sama saja membubarkan adat dan suku, serta takut pada kutukan leluhur atau embu mamo dan tanah watu. sedangkan dalam Pasal 19 UUPA dan dalam PP No. 24 Tahun 1997 Pasal 3 dan Pasal 4 bahwa Tujuan dari pendaftaran atas tanah yaitu akan tercapai :

1). Memberi kepastian hukum dan perlindungan hukum kepada pemegang hak atas suatu bidang tanah, satuan rumah susun dan hak-hak lain yang didaftar agar dengan mudah dapat membuktikan dirinya sebagai pemegang hak yang bersangkutan.

Jaminan kepastian hukum meliputi Kepastian :

(a) Status hak yang didaftar misalnya Hak Milik, HGU, HGB (b) Subyek hak artinya dengan pendaftaran tanah dapat diketahui dengan pasti pemegang haknya (perseorangan atau badan hukum). (c) Objek hak artinya dengan pendaftaran tanah dapat diketahui dengan pasti letak tanah, batas-batas tanah dan ukuran (luas) tanah.

2). Menyediakan informasi kepada 
pihak-pihak yang berkepentingan termasuk Pemerintah agar mudah dapat memperoleh data fisik dan data yuridis yang diperlukan dalam mengadakan perbuatan hukum mengenai bidangbidang tanah dan satuan-satuan rumah susun.

3). Terselenggaranya tertib administrasi pertanahan, Program Pemerintah dibidang pertanahan yaitu Catur Tertib Pertanahan meliputi Tertib Hukum Pertanahan, Tertib Administrasi Pertanahan, Tertib Penggunaan Tanah dan Tertib Pemeliharaan Tanah dan Kelestarian Lingkungan Hidup.

Dalam Jaminan Kepastian Hukum dan perlindungan hukum dari pendaftaran tanah maka kepada pemegang hak yang bersangkutan diberikan Sertifikat sebagai tanda bukti hak atas tanah adalah segala alat atau tanda apapun yang menurut undang undang yang resmi dan sah dapat digunakan untuk membuktikan hak seseorang atas tanah yang dimilikinya, sehingga orang tersebut memiliki kewenangan yang luas untuk menggunakan dan memanfaatkan tanah tersebut dengan tanpa adanya gangguan dari pihak lain serta diimplementasi dalam PP Nomor 24 Tahun 1997 dalam Pasal 1 butir 20 Peraturan bahwa : "Sertifikat adalah surat tanda bukti hak sebagaimana dimaksud dalam pasal 19 ayat 2 huruf c UUPA untuk hak atas tanah, hak pengelolaan tanah wakaf, hak milik atas satuan rumah susun, dan hak/ tanggungan yang masing-masing sudah dibukukan dalam buku tanah yang bersangkutan. Sertifikat berdasarkan Pasal 32 ayat (1) PP yaitu surat tanda bukti hak yang berlaku sebagai alat pembuktian yang kuat mengenai data fisik dan data yuridis yang termuat didalamnya, sepanjang data fisik dan data yuridis tersebut sesuai dengan data yang ada dalam surat ukur dan buku tanah yang bersangkutan.

Sedangkan menurut Kamus besar bahasa Indonesia pengertian dari Sertifikat yaitu tanda atau surat Keterangan (pernyataan tertulis atau cetak) dari orang yang berwenang yang dapat digunakan sebagai alat bukti pemilikan atau suatu kejadian. (Sertifikat Tanah merupakan surat bukti pemilikan tanah yang dikeluarkan oleh instansi yang berwenang) ${ }^{5}$ Sedangkan dalam Black's Law Dictionary menurut Bryan A.Garner, "Certificate is a document in which afact is formally attested" 6

Dalam Teori kepemilikan hukum Indonesia menganut sistem Eropa Kontinental yang tertuang dalam Kitab Undang-Undang Hukum Perdata, sebagaimana disebutkan dalam Pasal 570 Kitab Undang-Undang Hukum Perdata yaitu " Hak Milik adalah hak untuk menikmati suatu benda dengan sepenuhnya dan untuk menguasasi benda itu dengan sebebas-

5 Kamus Besar Bahasa Indonesia, Sertifikat, http://kbbi.web.id/sertifikat, diakses 22 April 2015 Pukul 11.00 WIB.

6 Gamer, Bryan A, Black's Law Dictionary, Abridged Seventh Edition, ST. Paul Minn, 2000, hlm. 177. 
bebasnya, asal tidak bertentangan dengan undang-undang atau peraturan umum yang diadakan oleh kekuasaan yang mempunyai wewenang untuk itu, asal tidak mengganggu hak orang lain, kesemuanya dengan tidak mengurangi kemungkinan pencabutan hak itu untuk kepentingan umum dengan pembayaran penggantian kerugian yang layak dan menurut ketentuan undang-undang"? 7

Teori pemilikan tanah berdasarkan hukum adat adalah tanah merupakan milik komunal atau persekutuan hukum (beschikkingsrecht). Dalam hal ini setiap anggota persekutuan dapat mengerjakan tanah dengan jalan membuka tanah terlebih dahulu dan jika mereka mengerjakan tanah tersebut secara terus-menerus maka tanah tersebut dapat menjadi hak milik secara individual.

Kekuatan hukum terhadap tanah adat yang telah bersertifikat di wilayah adat Kebirangga, jika disandingkan antara hukum adat yang berlaku bertolak belakang dengan hukum positif yang berlaku nasional, karena hukum adat di Kebirangga yang berlaku dipatuhi dan ditaati secara sukarela oleh masyarakat adat Kebirangga. Kehadiran hukum positif melalui Sertifikat tanah di wilayah adat Kebirangga sudah diakui oleh Mosalaki dengan mengijinkan tanah adat untuk disertifikat. Hal ini berarti bahwa ada pengaruh positif hukum agraria terhadap hukum adat saat ini, mesti masih bersifat saling melengkapi khususnya dalam mencegah perebutan lahan antar masyarakat adat, dan memastikan lahan yang sudah disertifikat menjadi hak yang dimanfaatkan dan dikelola oleh masyarakat adat (fai wazu ana azo), sedangkan yang belum disertifikat tetap menjadi milik Mosalaki Kebirangga.

Sehingga dalam wilayah adat Kebirangga diakui adanya pluralisme hukum yaitu hukum Nasional dan hukum adat sebagaimana dikemukakan oleh Savigny maupun Friedman, bahwa budaya hukum dalam hukum adat dan pluralisme hukum sangat penting karena Hukum yang ideal harus sesuai dengan budaya hukum di masyarakat (living law) berupa hukum adat atau hukum kebiasaan dalam pembentukan hukum Artinya, hukum adat dan pluralisme hukum merupakan kesatuan hukum dan fakta yang tidak dapat dipisahkan memandang bahwa semua hukum adalah sama dan harus diberlakukan sederajat.

B. Intervensi dari Kepala Adat (Mosalaki) berkaitan dengan Pembatasan Hak Pemilik Sertifikat Hak Milik atas Tanah berdasarkan Teori Kepastian Hukum

\section{Kewenangan Mosalaki terhadap tanah adat di wilayah ada Kebirangga}

Tanah bagi masyarakat adat suku Ende dan Lio sangat penting nilainya. Hal ini dapat dilihat dari ungkapan adat bermakna religius sebagaimana disampaikan oleh Bapak Yoseph

7 R. Roestandi Ardiwilaga, Hukum Agraria Indonesia dalam Teori dan Praktek, Masa Baru, Jakarta, 1962, hlm. 12. 
Mboro sebagai Mosalaki Kebirangga bahwa meskipun fai wazu ana azo sudah diberi bagian bidang tanah untuk dikelola dan dimanfaatkan dan telah disertifikatkan sebagai Hak milik atas tanah, tapi bukan berarti tanah dapat dialihkan dan dijual dengan kepada pihak lain oleh fai wazu ana azo.

Dimana kekuasaan Mosalaki yang mutlak di wilayah adat Kebirangga yaitu memimpin setiap seremoni adat yang dilaksanakan dalam hal ini kuasa untuk mengatur dan mengawasi tanah-tanah yang ada di wilayah adatnya, juga kewenangan melarang menjual tanah dalam bahasa adat diungkapkan yakni “ ina eo pati iwa do lai" artinya tanah pemberian saya tidak akan diambil kembali :" tii iwa do langa "yang artinya telah diletakan tidak lagi diangkat dan "pati taka noo lana" yang artinya pemberian telah melekat pada tanah.

Makna bahwa tanah yang telah diberikan pada fai wazu ana azo tidak akan diambil lagi namun dengan ketentuan tidak boleh dialihkan terutama dijual pada orang diluar wilayah adat Kebirangga dan pemanfaatan tanah sebatas mengelola, mendirikan tempat tinggal, lahan ternak serta diwariskan secara garis lurus pada anak laki-lakinya. Jika tanah pemberian Mosalaki dijual maka Mosalaki dalam kapasitasnya sebagai Kepala Adat mempunyai kewenangan akan mengambil tindakan yaitu memberi sanksi pada fai wazu ana azo berupa denda adat dengan melihat kemampuan finansial dari fai wazu ana azo dan sanksi yang terberat pengambilan kembali tanah tersebut. Dalam bahasa ada ada ungkapan Gaga paa ana yang artinya kerjakan tanah simpan untuk anak cucu, memiliki makna yang dalam dan bernilai magis hal tersebut dilakukan Mosalaki untuk menjaga dan melindungi wilayah adat yang wajib dilindungi dan menghormati tanah watu dan embu mamo, menjaga dan mempertahankan eksistensi adat Kebirangga karena kalau tanah telah dikuasai oleh orang luar adat Kebirangga maka mereka tidak mempunyai kewajiban mentaati ketentuan adat Kebirangga sehingga adat akan punah.

Mosalaki sebagai Ketua Adat mempunyai wewenang dan mengintervensi terhadap tanah yang berada dalam wilayah adatnya sebagai berikut :

(1). Adanya ungkapan secara adat yaitu "ina eo pati iwa do lai" artinya tanah pemberian saya tidak akan diambil kembali, : "tii iwa do langa" yang artinya telah diletakan tidak lagi diangkat dan "pati taka noo lana" yang artinya pemberian telah melekat pada tanah yang bermakna bahwa ucapan adat ini nilainya lebih tinggi dari nilai sertifikat karena pada saat memberikan tanah pada fai wazu ana azo meskipun dilakukan secara lisan namun mempunyai kekuatan yang mengikat antara tanah tersebut dengan fai wazu ana azo sebagai pemiliknya.

(2). Tanah yang dimiliki oleh fai wazu ana azo dengan hak atas tanah Hak Milik hanya sebatas mengelola dan memanfaatkan bidang tanah tersebut dan bukan berarti dengan Hak milik tanah 
dapat dialihkan dan dijual kepada pihak lain hal ini karena pada awal pembagian tanah telah adanya ketentuan adat bahwa tanah yang diberikan oleh Mosalaki tidak boleh dialihkan dalam hal ini dijual, dihibahkan maupun dijadikan jaminan kredit di Bank dengan Hak Tanggungan. Namun terhadap tanah tersebut dapat diwariskan pada keturunannya dengan garis patrilineal hanya untuk anak lakilakinya.

(3). Intervensi Mosalaki terhadap tanah dengan hak milik yang bersertifikat tersebut karena adanya kewajiban dari Mosalaki untuk menjaga dan melindungi adat Kebirangga yang artinya Mosalaki wajib melindungi dan menghormati tanah watu dan embu mamo guna melindungi eksistensi adat Kebirangga. ${ }^{8}$

Kekuasaan Mosalaki atas tanah di wilayah adat Kebirangga terkait erat dengan posisi struktur Mosalaki dalam adat Ende secara umum yang dikenal adanya pembagian fungsi dan peran seperti ada mosalaki Pu'u atau pemimpin tertinggi/utama, dan ada Mosalaki Ria Bewa atau sike sani/pembantu, didasarkan pada kedudukan secara historis dan genealogis, kedudukan antar Mosalaki tidak saling subordinat ( tidak saling membawahi), tetapi subservient ( saling melengkapi dalam pelayanan adat) sejarah kepemimpinan Mosalaki bersangkutan secara turun temurun memahami akan kedudukan, tugas dan fungsinya pada setiap momentum adat dan kapan terjadi peristiwa po,o dan neka tanah menurut hukum adat (seremoni adat). Penghargaan terhadap nilai ke-Mosalaki- an ini harus tercermin dari ungkapan :

“ kura faja no'o lowo-lowo, roa loka no'o keli-keli" yang bermakna mereka (Mosalaki) mempunyai kewenangan diwilayahnya masing-masing sehingga Mosalaki dapat menentukan bahwa meskipun tanah telah di Sertifikat oleh fai wazu ana azo tetapi sebatas pada dimanfaatkan sesuai fungsinya, serta harus mengikuti ketentuan adat karena sertifikat berkaitan dengan tanah, dan tanah berkaitan erat dengan hak ulayat yang dikepalai oleh Mosalaki.

Sehingga Mosalaki dapat mengintervensi tanahadatpadafaiwazuanaazo melaranguntuk mengalihkan yakni menjual, menjaminkan atau mengadaikan hal ini dianggap sebagai kewajaran bagi masyarakat adat Kebirangga karena adat telah menentukan demikian.

Dalam Teori Kepemilikan berdasarkan hukum adat tanah merupakan milik komunal atau persekutuan hukum, masyarakat adat hanya mengerjakan, mengelola atau memanfaatkan tanah tersebut dengan terlebih dahulu mendapat ijin dari Mosalaki, sehingga para fai wazu ana azo dapat mengelola tanah tersebut selama bertahun-tahun, dalam pelaksanaannya untuk menghindari perebutan lahan atau penyerobotan tanah maka Mosalaki membagi bidang-bidang tanah tersebut pada para fai wazu ana azo, dan untuk wilayah adat Kebirangga Kepala Adat (Mosalaki)

8 Wawancara dengan Bapak Yoseph Mboro, Mosalaki Kebirangga, 12 April 2015. 
mengijinkan fai wazu ana azo untuk menyertifikatkan bidang tanah tiap-tiap fai wazu ana azo sehingga terwujudnya kepastian hukum dan kepastian terhadap kepemilikan atas bidang tanah tersebut.

\section{Pembatasan hak bagi pemilik sertifikat hak milik atas tanah di wilayah adat Kebirangga}

Di wilayah adat Kebirangga bidang-bidang tanah yang telah dibagi oleh Mosalaki pada fai wazu ana azo dimanfaatkan untuk pertanian atau kebun guna memenuhi kebutuhan hidupnya maupun untuk membangun tempat tinggal.

Pada Tahun 2002 pemerintah dalam hal ini Badan Pertanahan Nasional Kabupaten Ende melaksanakan proyek Operasi Nasional Agraria (PRONA) dan dengan penuh kesadaran Mosalaki mengijinkan tanah yang telah dibagikan ke para fai wazu ana azo tersebut untuk didaftarkan sehingga bagi pemilik tanah bisa mempunyai sertifikat dan ada kepastian hukum terhadap batas-batas tanah yang menjadi haknya serta merupakan alat bukti yang terkuat bila terjadi sengketa ( misalnya penyerobotan tanah atau sengketa mengenai batas tanah). Namun secara adat tetap harus diakui bahwa tanah tersebut tidak dilepas dari ketentuan adat Kebirangga.

Hak menguasai tanah menurut hukum adat tetap menjadi hak Mosalaki dan para pemegang sertifikat tetap dipandang sebagai penggarap hal ini sesuai dengan ketentuan adat dan merupakan pembatasan hak atas tanah sehingga fai wazu ana azo wajib tunduk dan taat pada ketentuan adat serta wajib hadir dalam setiap pelaksanaan upacara/ seremoni adat, misalnya peletakan batu pertama dalam pembangunan atau neka tanah yang merupakan upacara menggali fondasi awal pembangunan rumah. Seremoni Po,o yaitu upacara adat untuk memulai musim tanam, para fai wazu ana azo diwajibkan membawa apa yang menjadi kewajiban mereka sesuai ketentuan yang ditetapkan dan diputuskan oleh Mosalaki dalam seremoni Po,o tahun sebelumnya. Serta yang paling penting yaitu tanah yang diperoleh tidak boleh dijual, dialihkan maupun dijadikan jaminan di Bank. Dengan pengecualian bagi pemegang sertifikat tanah, mereka harus meminta ijin ke Mosalaki untuk mengadaikan tanah atau menjaminkan tanah tersebut dengan alasan modal usaha, memenuhi kebutuhan hidup, kesehatan atau pendidikan serta wajib melunasi utang di bank secara tepat waktu agar tanah tersebut tidak dieksekusi.

Menurut Bapak Hendrikus Mberha selaku Mosalaki Owe Joje (Mosalaki tetangga dari Mosalaki Kebirangga) mengatakan bahwa mengenai kekuatan dari Sertifikat hak milik atas tanah sebagai berikut:

"Meski masyarakat atau fai wazu ana azo telah memiliki sertifikat, tetapi bukan berarti hak Mosalaki (kepala suku) hilang. Hak Mosalaki dari dulu hingga kapanpun dan generasi kedepan pun tetap akan berjalan karena tanah ada kaitan erat dengan kepemilikan oleh Mosalaki yaitu keturunan pertama yang membuka hutan untuk pertama kalinya diwilayah ini. Dan hal ini 
sudah berlangsung turun temurun dari masa lalu hingga generasi kami ini.

Buktinya meski sudah ada Sertifikat tapi hak adat Mosalaki tetap kami jalankan dan fai walu ana azo wajib taat, karena tanah yang ini merupakan warisan orang tua kita dan merupakan tanah milik adat.

Jika ketentuan hukum adat dalam seremoni adat ini tidak ditaati maka pasti kena denda adat berupa kewajiban membayar ternak dan tuntutan lainnya sesuai Keputusan /Ketetapan Mosalaki karena dari dulu denda adat seperti ini sudah ada dan masih dijalankan dengan baik". 9

Contoh kasus terbatasnya hak bagi pemilik tanah atas hak milik yang telah bersertifikat di wilayah adat Kebirangga sebagaimana disampaikan oleh Bapak Al Amin warga RW Nioniba Desa Kebirangga yang mengatakan bahwa: Tanah-tanah yang telah dibagikan tersebut secara hukum adat telah ditentukan hanya boleh digarap atau dimanfaatkan untuk mendirikan rumah tinggal dan tidak boleh dijual karena sebagai fai wazu ana azo secara sukarela mengikuti ketentuan adat tersebut hal ini, kalau mau dijaminkan tapi harus seijin Mosalaki dengan perjanjian akan membayar pinjaman agar tanah tidak disita dan para fai wazu ana azo wajib ikut seremoni adat dan tidak melanggar nilai adat dalam suku di Kebirangga. ${ }^{10}$

Kasus yang lain dimana tanah diambil lagi oleh Mosalaki karena dijual tanpa ijin dari Mosalaki sebagaimana yang dialami oleh Bapak Ali Mudin yang tanah pemberian Mosalaki diambil kembali karena telah melanggar ketentuan adat yaitu menjual tanah yang menjadi bagiannya. Sebagaimana pernyataan dari Mosalaki Kebirangga bapak Yoseph Mboro yaitu sebagai berikut:

"Saya tarik kembali karena tanah diberikan secara cuma-cuma untuk diolah guna memenuhi kebutuhan hidup maupun untuk mendirikan tempat tinggal bukan untuk dijual karena jika dijual berarti orang yang menjual tanah telah tahu akan sanksi adat serta yang bersangkutan telah memutuskan persekutuannya dengan wilayah adat Kebirangga, sehingga saya selaku Mosalaki mempunyai hak memberikan sanksi dengan mengambil kembali tanah tersebut dan mengalihkan ke pihak lain yang membutuhkan yakni tanah tersebut saya serahkan pada Pemerintah Daerah untuk dijadikan Terminal Kecamatan Maukaro.

\section{Kewajiban untuk mengikuti semua seremonial/ upacara adat bagi para masyarakat adat Kebirangga}

Kekuasaan dari Mosalaki selaku kepala adat mempunyai kewenangan melakukan seremonial adat dengan bahasa adat dan dapat berhubungan langsung dengan Tuhan sang penguasa langit (nggae dewa), dan Tuhan sang penguasa bumi (embu mamo atau tanah watu) lengkap dengan nama mereka serta silsilah keturunan suku mereka.

9 Wawancara dengan Bapak Hendrikus Mberha, Mosalaki Owe Joje, 15 April 2015.

10 Wawancara dengan Bapak Al Amin, Warga RW Nioniba Desa Kebirangga, 14 April 2015. 
Dalam pelaksanaan seremoni adat peran Mosalaki sebagai penghubung antara pribadipribadi yang masih hidup (Mosalaki dan masyarakat adatnya) dengan arwah leluhur yang sudah meninggal terutama Tuhan sang pencipta yang disampaikan lewat syair-syair atau petuah-petuah adat.

Kewajiban bagi setiap fai wazu ana azo yang mempunyai tanah berdasarkan hasil pemberian oleh Mosalaki wajib membawa beras, hewan/ayam, arak/ tuak/ moke dan sejumlah uang sesuai ketentuan dari Mosalaki dan akan disanggupi oleh para fai wazu ana azo. Menurut Bapak Phelipus Kami selaku Ketua Aliansi Masyarakat Adat Nusantara (AMAN) Kabupaten Ende menyampaikan bahwa:

"Keberadaan masyarakat adat dan peran serta fungsinya dibawah kekuasaan para Mosalaki dalam konteks Kabupaten Ende ada sebagian sudah mulai luntur terutama dalam hak penguasaan tanah ulayat wilayah adat khususnya di Kota Ende. Sedangkan untuk diluar Kota Ende ada 3 ( tiga ) gejala yang kami temukan yakni

Pertama, Ada hak ulayat yang sudah dibagikan oleh Mosalaki sebagai penguasa ulayat kepada para fai walu anakalo / fai wazu ana azo (anggota komunitas adat) untuk disertifikatkan atas nama pribadi fai walu ana kalo/fai wazu ana azo, dengan ketentuan kepemilikan sertifikat atas tanah ulayat pemberian dari Mosalaki bukan untuk dijual kepada pihak lain, melainkan diolah untuk peningkatan ekonomi keluarga.

Hal ini terjadi di Kecamatan Maukaro seperti desa Kebirangga, Kebirangga Tengah, Kamubheka dan Kolikapa sebagian tanah ulayat di Kecamatan Maurole, sebagian tanah adat di Kecamatan Wolowaru (Kota wolowaru).

Kedua, Ada Mosalaki yang belum mengijinkan para fai walu ana kalo/ fai wazu ana azo untuk mensertifikatkan tanah ulayat atas nama pribadi para fai walu ana kalo/fai wazu ana azo, sehingga hingga saat ini belum disertifikat terutama di Kecamatan Lepembusu Kelisoke, Kecamatan Detukeli, Kecamatan Kota Baru, Kecamatan Wewaria, Kecamatan Detusoko, Kecamatan Wolowaru, Kecamatan Lio Timur, Kecamatan Wolojita, Kecamatan Ndona Timur, Kecamatan Ndona, Kecamatan Kelimutu, Kecamatan Ende dan Kecamatan Nangapanda karena peranan Mosalaki masih sangat dominan.

Ketiga, Khusus di Kota Ende yang meliputi 4 (empat) Kecamatan dalam Kota peran Mosalaki sudah mulai hilang sehingga kepemilikan tanah telah beralih dari komunal menjadi pribadi. Masuk dalam kelompok ini adalah para Mosalaki yang beragama Muslim yang mengenal pembagian warisan harus merata untuk semua anak. ${ }^{11}$ 
Menurut pendapat Boedi Harsono subyek Hak Ulayat adalah Masyarakat hukum adat yang mendiami suatu wilayah tertentu. ${ }^{12}$ Sehingga Tanah ulayat didefenisikan sebagai sebidang tanah yang diatas permukaannya melekat hak purba dari suatu masyarakat hukum adat tertentu serta kewenangan yang menurut hukum adat, dimiliki dan dikuasai serta dimanfaatkan oleh persekutuan masyarakat hukum adat atas wilayah tertentu yang merupakan lingkungan warganya, dimana kewenangan ini memperbolehkan masyarakat adat atas persetujuan ketua adat untuk mengambil manfaat dan keuntungan sebesar-besarnya dari sumber daya alam termasuk tanah dan sesuatu yang terkandung di dalamnya, ruang angkasa dan sumber daya airnya dalam wilayah tersebut bagi kelangsungan hidupnya.

Hal ini searah dengan pendapat Gustav Radbruch yang mengatakan bahwa mengenai hal mendasar yang terkait dengan kepastian hukum ialah:

1). Hukum itu positif adalah perundangundangan.

2). Hukum itu harus didasarkan pada fakta adalah mesti didasarkan pada kenyataan yang ada di masyarakat.

3). Fakta harus dirumuskan dengan cara yang jelas sehingga menghindari kekeliruan dalam pemaknaan, di samping mudah dilaksanakan.
4). Hukum positif tidak boleh mudah diubah oleh masyarakat akan tetapi harus melewati proses legislasi bersama lembaga legislator."13

Yang mana suatu kepastian merupakan ciri yang tidak dapat dipisahkan dari hukum baik hukum yang tertulis maupun hukum yang tidak tertulis yang telah hidup dalam suatu masyarakat, Namun Kepastian terutama untuk norma hukum tertulis. Hukum tanpa nilai kepastian akan kehilangan makna karena tidak dapat lagi digunakan sebagai pedoman perilaku bagi setiap orang. Kepastian sendiri disebut sebagai salah satu tujuan dari hukum.

Keteraturan masyarakat berkaitan erat dengan kepastian dalam hukum, karena keteraturan merupakan inti dari kepastian itu sendiri. Keteraturan menyebabkan orang dapat hidup dan dapat melakukan kegiatankegiatan yang diperlukan dalam kehidupan bermasyarakat.

Guna memahami secara jelas mengenai kepastian hukum itu sendiri berikut ini penulis kemukakan juga Kepastian Hukum menurut Jan M. Otto dalam Sidharta, menjelaskan bahwa kepastian hukum dalam situasi tertentu harus mensyaratkan hal-hal sebagai berikut:

1). Tersedianya aturan-aturan hukum yang jelas, konsisten dan mudah diperoleh (accesible), yang diterbitkan oleh kekuasaan negara yang sah;

11 Makalah dengan judul Masyarakat adat dan Demokrasi yang disampaikan oleh Ketua Aliansi Masyarakat Adat Nusantara (AMAN) Kabupaten Ende (Bapak PHELIPUS KAMI) yang disampaikan dalam Forum Adat tanggal 8 Agustus 2014 di Sao Ria Kota Ende.

12 Boedi Harsono, Op.cit., hlm. 190.

13 Ngobrolin hukum, Memahami Kepastian dalam Hukum, http:// ngobrolinhukum.com/2013/02/05/ memahami-kepastian-dalam-hukum/, diakses 18 Desember 2014 pukul 06.10 WIB. 
2). Instansi-instansi

penguasa

(pemerintahan) menerapkan aturanaturan hukum tersebut kepada masyarakat secara konsisten dan juga tunduk dan taat kepadanya;

3). Mayoritas warga masyarakat pada prinsipnya menyetujui substansi hukum dan karena itu menyesuaikan perilaku mereka terhadap aturan-aturan tersebut;

4). Hakim-hakim pada lembaga (peradilan) yang mandiri dan tidak berpihak menerapkan aturan-aturan hukum tersebut secara konsisten sewaktu mereka menyelesaikan sengketa hukum; dan

5). Keputusan peradilan secara nyata dilaksanakan di masyarakat. ${ }^{14}$

Dalam 5 (lima) syarat tersebut menjelaskan bahwa kepastian hukum akan terwujud dengan substansi/isi hukum yang sesuai dengan kebutuhan di dalam masyarakat yang terwujud dalam prilaku kehidupan dalam masyarakat tersebut.

Analisa dari pendapat ahli tersebut diatas maka suatu kepastian hukum yang berlaku di dalam pengaturan hidup masyarakat maka diperlukan adanya suatu ketentuan hukum yang pasti serta ditaati dan peraturan perundang-undangan yang dibuat oleh negara mempunyai kemampuan dan pasti ditaati sesuai aspek yuridis sebagai penjaminnya baik hukum tertulis maupun hukum yang tidak tertulis yang telah ada dan hidup di dalam lingkungan masyarakat adat tertentu.
Pasal 19 UUPA dalam hal ini menjamin adanya kepastian hukum terhadap bidang tanah apabila telah didaftarkan, implementasi dari pasal ini dalam Peraturan Pemerintah Nomor 24 Tahun 1997 merupakan peraturan pelaksanaan dari kegiatan pendaftaran tanah akan mewujudkan kepastian hukum kepada pemegang hak atas tanah serta perlindungan hukum bagi pemegang hak atas tanah atas gugatan pihak ketiga yakni dalam Pasal Pasal 3 dan Pasal 4 dalam Peraturan Pemerintah Nomor 24 Tahun 1997 yakni :

a. Memberikan kepastian hukum dan memberikan perlindungan hukum kepada pemegang hak atas bidang tanah,suatu satuan rumah susun dan hak-hak lainnya yang terdaftar agar dengan mudah dapat membuktikan dirinya sebagai pemegang hak yang bersangkutan. (terbukti dalam Sertifikat yang merupakan hak pemegang hak atas tanah yang dijamin oleh undang-undang)

b. Menyediakan Informasi kepada pihakpihak yang berkepentingan termasuk Pemerintah agar dengan mudah dapat memperoleh data-data yang diperlukan dalam mengadakan perbuatan-perbuatan hukum mengenai bidang tanah dan suatu satuan rumah susun yang sudah terdaftar misalnya pengadaan tanah untuk kepentingan Pemerintah atau kepentingan swasta, jual-beli, lelang, pembebanan Hak Tanggungan. 
c. Terselenggaranya tertib administrasi bidang pertanahan dikenal dengan Catur Tertib Pertanahan yaitu Tertib Hukum Pertanahan, Tertib Administrasi Pertanahan, Tertib Penggunaan Pertanahan dan Tertib Pemeliharaan Pertanahan dan Lingkungan Hidup. ${ }^{15}$

Dengan adanya suatu kepastian hukum atau aturan- aturan yang hidup dan ditaati oleh suatu masyarakat secara suka rela karena diyakini akan membawa ketertiban dan keteraturan dalam kehidupan bersama dalam suatu wilayah sebagaimana dalam Masyarakat Adat Kebirangga kewenangan penguasa Adat yaitu Mosalaki sebagai tokoh sentral yang mempunyai pengguasaan penuh terhadap tatanan hidup masyarakat adat khususnya atas tanah ulayat sedangkan para fai wazu ana azo status hanya sebatas sebagai penggarap atas tanah yang diberikan oleh Mosalaki. Hubungan antara Mosalaki dan penggarap ( $f a i$ wazu ana azo) dari zaman dahulu hingga saat ini, lebih bersifat vertikal dan berlangsung melalui mekanisme transaksi usaha seperti Mosalaki menyediakan tanah untuk dikelola, sedangkan para penggarap mempunyai kewajiban menyisihkan hasil pertaniannya untuk diserahkan kepada Mosalaki sebagai upeti.

Dalam proses peralihan hak atas tanah dan pendaftarannya bermuara dengan diterbitkannya sertifikat. Namun maksud diterbitkan Serifikat dalam kegiatan pendaftaran tanah agar pemegang hak dengan mudah dapat membuktikan bahwa dirinya sebagai pemegang hak serta dapat membuktikan jaminan kepastian hukum dan perlindungan hukum bagi pemegang hak, bagi wilayah adat Kebirangga belum dilaksanakan berdasarkan ketentuan Peraturan Pemerintah tersebut karena masih kuatnya ketentuan Hukum adat yang berlaku bagi pemilik dan pembuktian dari masyarakat adat secara khusus di wilayah adat Kebirangga.

\section{Simpulan}

\section{Kekuatan Hukum dari Sertifikat Hak Milik atas tanah di wilayah adat Kebirangga Kecamatan Maukaro berdasarkan pelaksanaan penyertifikatan tanah adat}

Secara internal dalam suku Kebirangga Kekuatan hukum adat lebih kuat berlaku dan ditaati dari hukum positif negara sehingga ada pembatasan kepemilikan atas tanah oleh Mosalaki yang dapat diukur dari empat (4) hal yaitu;

(1) Pengalihan terhadap hak atas tanah yaitu untuk menjual-belikan tanah, menggadaikan tanah atau menjaminkan dengan hak tanggungan ke Bank harus ada pemberitahuan kepada (seijin) Mosalaki. 
(2) Para pemegang sertifikat fai wazu ana azo dapat mewariskan bidang tanahnya ke keturunan garis lurus yakni anak lakilakinya;

(3) Para pemegang sertifikat wajib dan tunduk kepada ketentuan hukum adat yaitu bahwa tanah yang dibagikan pada fai wazu ana azo oleh Mosalaki hanya sebatas dimanfaatkan untuk mendirikan tempat tinggal dan dikelola sebagai kebun atau sawah guna memenuhi kebutuhan hidup mereka dan tidak boleh menjual dan menggadaikan/ menjaminkan tanah secara bebas sebagai pemegang hak milik atas tanahnya, serta terikat sebagai anggota masyarakat adat secara aktif harus selalu mentaati segala kewajiban yang ditetapkan oleh Mosalaki guna mengikuti seremoni/upacara adat yang dilakukan di wilayah adat Kebirangga.

(4) Mengakui Mosalaki sebagai pemilik tanah adat yang tertinggi dan para pemegang sertifikat hak milik atas tanah tetap sebagai penggarap tanah Mosalaki tersebut.

Secara eksternal, Kekuatan hukum dari sertifikat hak milik dalam hubungan dengan suku lain/suku tentangga yaitu :

(1) Adanya pengakuan dari suku tetangga terhadap batas-batas hak ulayat atau tanah adat Kebirangga karena secara hukum adat mereka saling mengakui batas-batas ulayat mereka meski secara lisan dalam bentuk ungkapan adat tana Kebi (tanah adalah Kebi) dan watu Rangga (batu adalah Rangga) dan semakin diperkuat dengan adanya sertifikat sehingga dapat menjamin kepastian batas wilayah antar wilayah adat.

(2) Apabila ada anggota suku lain yang hendak membeli tanah di dalam wilayah adat Kebiranga dan atau sebaliknya, maka yang bersangkutan secara otomatis menjadi masyarakat adat Kebirangga dan penggarap tanah suku Mosalaki Kebirangga dan wajib terikat dengan semua ketentuan adat yang berlaku di wilayah adat Kebirangga, dan atau sebaliknya dari suku Kebirangga terhadap suku yang lain.

Di wilayah adat Kebirangga di Kecamatan Maukaro belum mampu menghilangkan peran hukum adat khusus dalam penguasaan hak atas tanah dari Mosalaki sebagai Kepala adat, meskipun telah ada sertifikat hak milik atas nama masing-masing orang (fai wazu ana azo), sehingga hak milik masih menjadi hak Mosalaki yang berlaku hingga saat ini, merupakan fakta masih adanya pertentangan akan kepemilikan berdasarkan ketentuan hukum positif dan kepastian hukum antara hukum positif dan hukum adat. 
2. Intervensi dari Kepala adat (Mosalaki) berkaitan dengan pembatasan hak bagi pemilik sertifikat hak milik atas tanah berdasarkan teori Kepastian Hukum

Penguasa Adat pada wilayah adat Kebirangga yaitu Mosalaki sebagai tokoh sentral yang mempunyai pengguasaan penuh terhadap tatanan hidup masyarakat adat khususnya pengguasaan atas tanah ulayat sedangkan para anggota anak suku/ fai watu ana azo status hanya sebatas sebagai penggarap atas tanah yang diberikan oleh Mosalaki. Hubungan antara Mosalaki dan penggarap (fai wazu ana azo) dari zaman dahulu hingga saat ini, lebih bersifat vertikal yangmana Mosalaki menyediakan tanah untuk dikelola, sedangkan para penggarap mempunyai kewajiban mengelola tanah tersebut untuk memenuhi kebutuhan hidupnya dengan menyisihkan hasil pertaniannya untuk diserahkan kepada Mosalaki sebagai upeti. Pemberian upeti baik jumlah maupun mutu bervariasi sesuai nilai adat yang berlaku dan dipatuhi dengan segenap hati yang oleh penggarap untuk diserahkan kepada Mosalaki dapat berbentuk hasil dari pengolahan tanah ulayat dan dapat pula berbentuk uang tunai pada upacara adat/ peristiwa adat tertentu misalnya : saat upacara perkawinan, upacara kematian, pembuatan fondasi rumah atau seremoni adat lainnya.

Merupakan kenyataan dalam hidup bermasyarakat diperlukan aturan-aturan yang bersifat umum dan guna kepentingan yang ada di masyarakat terlindungi dan sedemokratis dengan adanya suatu kepastian hukum atau aturan- aturan yang hidup dan ditaati oleh suatu masyarakat secara suka rela karena diyakini akan membawa ketertiban dan keteraturan dalam kehidupan bersama dalam suatu wilayah.

Sehingga setiap tatanan kehidupan di wilayah adat Kebirangga tersebut diatur oleh Mosalaki berdasarkan Ketentuan adat yang telah hidup dan ditaati oelh masyarakat adatnya dan apabila fai wazu ana azo melakukan pelanggaran maka akan dikenai sanksi adat.

\section{DAFTAR PUSTAKA}

\section{Buku}

Boedi Harsono, 2008, Hukum Agraria Indonesia (Himpunan Peraturanperaturan Hukum Tanah) , Djambatan, Jakarta.
Fifik Wiryani, 2009, Reformasi Hak Ulayat Pengaturan Hak-hak Masyarakat Adat dalam pengelolaan Sumber Daya Alam, Setara Press, Malang.

I Gede A.B.Wiranata, 2006, Hukum Adat Indonesia, Cetakan Ke-1, Citra Aditya Bakti, Bandung. 
R. Roestandi Ardiwilaga, 1962, Hukum

Agraria Indonesia dalam Teori dan

Praktek, Masa Baru, Jakarta.

Samun Ismaya, 2011, Pengantar Hukum

Agraria, Graha Ilmu, Yogyakarta.

Soerjono Soekanto, Hukum Adat Indonesia,

Cetakan Ke-12, 2012, RajaGrafindo Persada, Jakarta.

\section{Makalah}

Makalah dengan judul Masyarakat adat dan Demokrasi, yang disampaikan oleh Ketua Aliansi Masyarakat Adat Nusantara (AMAN) Kabupaten Ende (Bapak Phelipus Kami) yang disampaikan dalam Forum Adat tanggal 8 Agustus 2014 di Sao Ria Kota Ende

\section{Peraturan Perundang-undangan}

Undang-undang Nomor 5 Tahun 1960 tentang Ketentuan Undang-undang Pokok Agraria (UUPA).

Peraturan Pemerintah Nomor 24 Tahun 1997 tentang Pendaftaran Hak atas Tanah.

Peraturan Presiden Nomor 10 Tahun 1997 tentang Badan Pertanahan Nasional.
Peraturan Menteri Negara Agraria/Kepala Badan Pertanahan Nasional Nomor 5 Tahun 1999 tentang Penyelesaian Masalah Ulayat Masyarakat Hukum Adat.

Keputusan Presiden Nomor. 10 Tahun 2006 tentang Badan Pertanahan Nasional.

Peraturan Menteri Agraria/ Kepala BPN No. 3 Tahun 1997 tentang Peraturan pelaksanaan Peraturan Pemerintah No. 27 Tahun 1997 tentang Pendaftaran Tanah.

\section{Naskah Internet}

Kamus Besar Bahasa Indonesia, Sertifikat, http://kbbi.web.id/sertifikat.

Ngobrolin hukum, Memahami Kepastian dalam hukum, http://ngobrolinhukum. com/2013/02/05/memahami-kepastiandalam-hukum/.

\section{Kamus}

Garner, Bryan A., 1999, Black's Law Dictionary, Seventh Edition, West Group, St. Paul Minnesota, USA.

Dzulkifli Umar dan Jimmy P., 2012, Kamus

Hukum (Dictionary of Law), Grahamedia Press, Surabaya. 